\title{
An Investigation on the Legislative Tradition of Should Be Rough Rather Than Detailed in China's Marriage Law_Also on the Early Practice of Chinese Feminist Movement
}

\author{
Yining $\mathrm{Hou}^{1}$ \\ ${ }^{1}$ School of Law, Beijing Normal University, Beijing, China \\ Correspondence: Yining Hou, Beijing Normal University, Beijing, 100875, China. Tel: 86-152-3416-0157. \\ E-mail: 553890567@qq.com
}

Received: July 5, $2021 \quad$ Accepted: July 21, $2021 \quad$ Online Published: July 31, 2021

doi:10.5539/ass.v17n8p38

URL: https://doi.org/10.5539/ass.v17n8p38

\begin{abstract}
The Civil Code of the People's Republic of China, which was reviewed and passed in May 2020, continues the tradition of should be rough rather than detailed in China's marriage and family legislation since the promulgation of the Marriage Law of 1950. The embodiment of this tradition in the marriage law text is fewer legal provisions, more general provisions, and more moral norms. This legislative tradition did not come from the Soviet Union but was mainly due to the unique legal nature of the Marriage Law of 1950. This law is the product of the victory of the Chinese feminist movement since the Revolution of 1911. Its legislative tradition of should be rough rather than detailed is determined by the legislative purpose of this law to break the feudal marriage system and protect the rights of women and children, and its unique legal attributes. The formulation of this law was subject to the legislative difficulties and the social reality faced by the marriage law drafting group centered on women leaders. It was a helpless choice in a particular period. In the modern society where China's economy, society, and marriage and family relations have undergone significant changes, it is crucial to improve marriage legislation and reverse the legislation tradition of should be rough rather than detailed, so that the improvement of legislative techniques and legislative goals meet the needs of economic and social development.
\end{abstract}

Keywords: China's marriage law, legislative tradition of should be rough rather than detailed, feminist movement

\section{Introduction}

On May 28, 2020, after deliberation at the Third Session of the Thirteenth National People's Congress of the People's Republic of China, the Civil Code of the People's Republic of China was passed. The legal provisions on marriage and family relations are included in the Marriage and Family Chapter. Before this, the laws of the People's Republic of China on marriage and family relations were named after the Marriage Law of the People's Republic of China (after this referred to as the Marriage Law), which was independent of the civil law and was implemented as a separate law. For example, the Marriage Law of 1950 and 1980, and the Marriage Law Amendment Act of 2001.

The Marriage and Family Chapter of the Civil Code contain 79 articles from 1,040 to 1,118, divided into five chapters: general regulations, marriage, family relations, divorce, and adoption. Although the legislative style of the Marriage and Family Chapter of the Civil Code has changed, its content has the same characteristics as the texts of the Marriage Law mentioned before. In terms of specific provisions on marriage and family relations, there are fewer provisions, more general provisions, and more moral norms. For a long time, people have believed that should be rough rather than detailed is China's legislative tradition, which means legislation should be rough and concise, not elaborate and refined. As early as the drafting of the Marriage and Family Chapter of the Civil Code, some scholars pointed out that the lack of content in the Marriage and Family Chapter is a continuation of the legislative tradition of should be rough rather than detailed in the Marriage Law of 1950.

2. The Embodiment of the Legislative Tradition of Should Be Rough Rather Than Detailed in the Marriage Law Text

Legislative tradition is the continuity of legislation caused by the legal system, legal ideas, and legislative techniques. In China, marriage and family relations were once governed by the Marriage Law of 1950 and1980, 
the Marriage Law Amendment Act of 2001, and other laws. From January 1, 2021, the Marriage and Family Chapter of the Civil Code will play the above role. By examining the above four marriage law texts, we can find that the legislative tradition of should be rough rather than detailed impacts the legal text, a concise legislative style.

First, there are few provisions in China's marriage law. There are eight chapters and 27 articles in the Marriage Law of 1950, which stipulate marriage and divorce, the rights and obligations between husband and wife, and the relationship between parents and children. The Marriage Law of 1980 has five chapters and 37 articles, including marriage, divorce, and family relations. The Marriage Law Amendment Act of 2001 was based on the text of the 1980 Marriage Law, which added relief measures and legal responsibilities as chapter V. This chapter conducts special legal regulations for the phenomenon of domestic violence, abandonment, or bigamy that damages the rights of family members in social practice. At the same time, it adds normative clauses for cohabitation and domestic violence and stipulates the invalidity and revocation of marriage. The entire text of the Marriage Law has been increased to 51 articles. The law also clarifies the scope of the joint property in marriage, the scope of property of one party, the practical rules of property agreement. It stipulates the circumstances under which the people's court may grant a divorce.

Second, there are more moral norms in China's marriage law. The first chapter of the Marriage Law of 1950 was named after Principles. Article 1 of the law stipulates freedom of marriage, a monogamous marriage system, equal political rights for men and women, and protection of women and children. The second article is a compulsory clause that prohibits bigamy, concubine, child brides-in-law, interference with the freedom of marriage, and the act of obtaining property through marriage. The primary goal of the entire legal text is to give women political rights and define the rights and obligations of family members. The specific situations stipulated by the law are briefly listed by way of examples.

Principled norms are also embodied in many articles of the Marriage Law of 1950. For example, Article 3 stipulates that "Marriage requires the full volition of the man and woman, and neither party nor any third party is allowed to force or to interfere the other party." Article 7 stipulates that "husbands and wives are partners living together and have equal status in the family." Article 10 stipulates that "both spouses shall have equal ownership and disposal rights to family property." Article 17 stipulates that "If both men and women divorce voluntarily, divorce shall be granted." The provisions on freedom of marriage, equal status of both spouses in marriage, and equal property rights have finally formed moral norms such as freedom of marriage, equality of husband and wife, and freedom of divorce.

Inheriting the core principles of the Marriage Law of 1950, the Marriage Law of 1980 adjusted the arrangement of the chapter structure. The law incorporates the basic principles of family planning, which means controlling the number of children in a family and a couple can only have one child, into the marriage law. The law also makes "The marriage did break down, and court mediation was useless" as the legal condition for divorce judgments. The above clauses all represent general principles.

The 2001 Amendment to the Marriage Law provides detailed regulations on the circumstances under which marriages are invalid and revocable and the circumstances under which divorce can be granted when the courts hear divorce cases. However, the law's provisions on the phenomena of extramarital cohabitation and domestic violence appearing in society are also general principles but not detailed provisions. For example, the third article of the law adds the content prohibition of married persons from cohabiting with others. Article 43 of the law gives victims of domestic violence the right to petition. At the same time, it stipulates the rights and responsibilities of residents committees, village committees, public security organs, and other relevant departments in responding to domestic violence incidents.

Third, the legal provisions that can be invoked to deal with specific marriage and family relationship disputes are not detailed enough, and judicial interpretations are needed to resolve specific legal cases.

Fourth, a complete system of legal concepts and legal norms has not been formed. The abstract legal concepts formed in previous marriage law texts are limited and fail to achieve the standards and requirements of refined legislation. Some scholars pointed out that "The family relationship itself is a relationship that is not suitable for abstraction and conceptualization," the flaws in legislative technology make this problem more prominent.

The legislative tradition of "should be rough rather than detailed" has been embodied in the previous Chinese marriage law texts as described above. As for the Marriage and Family Chapter of the Civil Code published in 2020 , the content of the provisions is still skinny compared with that of the property chapters of the Code. There are 79 articles of marriage and family in the Civil Code, which only account for $6.3 \%$ of the 1,260 articles of the Civil Code. The Marriage and Family Chapter of the Civil Code integrate the original marriage law and adoption 
law and is divided into five chapters: General Regulations, Marriage, Family Relations, Divorce, and Adoption. Among them, the newly added chapter on adoption includes 26 articles from Article 1093 to Article 1118. There is no significant change in the number of articles in the original marriage law. The main change in content is the addition of general provisions for relatives, close relatives, and family members. The law pioneered the "registration of divorce cooling-off period" clause, and at the same time, increased the daily family agency clause. The rules of the law on the joint property of husband and wife, joint debt, and division of joint property during the marriage have also been refined. However, the legislative value pursuit of "freedom of marriage, monogamy, equality between men and women, and protection of the legal rights and interests of women and children" and the legislative, technical tradition of "should be rough rather than detailed" established since the Marriage Law of 1950 has not changed.

Based on the above situation, the academic circles have reached a consensus on simplifying the provisions of the Chinese Marriage Law. However, we should examine where the legislative tradition of "should be rough rather than detailed" comes from, which is considered the reason for the simplification of the provisions of the Chinese marriage law and how it has been continuously adopted in Chinese marriage and family legislation.

\section{The Legislative Tradition of "Should Be Rough Rather Than Detailed" in the Marriage Law Does Not Come from Soviet Russia}

It is generally believed that the legislative tradition of Chinese marriage law comes from the Soviet Union. The early Chinese revolution was influenced by the Soviet-Russian October Revolution and international communism, and the legal systems also have a very close relationship with the Soviet Union. The socialist legal system was established after the founding of the People's Republic of China, completely abolished the six-law system of the Nationalist Government and absorbed Soviet law to establish a revolutionary legal system, and gradually formed a political and legal tradition that is still influential. The problem here is what traditions in the Soviet Union have affected our marriage law so that the marriage law has its current form.

According to research, the influence of Soviet law on China's legal system after 1949 is mainly in the following three aspects. First, follow the example of the Soviet Union to build a departmental law system. In constructing the legal system after 1949, China has borrowed mainly from the Soviet model at that time. In 1950, China's first marriage law was formulated regarding the Soviet-Russian Marriage, Family, and Guardianship Code. China's 1954 Constitution is also based on the Soviet Union's 1936 Constitution. Second, China's judicial system is also modeled after the Soviet Union. For example, the establishment of the court and the relationship between the lower and lower courts, the people's juror system, trial organization, criminal sentencing principles, trial procedures. Thirdly, Soviet legal experts intensely participated in the early construction of China's legal system. In 1951, Dong Biwu, then Vice Premier of the State Council, who was in charge of China's political and legal work, spoke highly of the contributions made by Soviet experts to the construction of China's legal system. He pointed out: "(Soviet experts) directly participated in the drafting or provided opinions on the various laws and regulations that we have created or drafted. They made timely suggestions on the work of the political and legal departments and systematically introduced the advanced Soviet experience. At the same time, they have given many lectures on the state and law of the Soviet Union for the staff of the various political and legal departments of the central government and affiliated schools and organizations." This suffices to explain the extent to which the Soviet Union influenced China's legal system at that time.

This kind of influence from the Soviet Union's legislation is also inextricable in the Chinese marriage law. However, it can be seen from the "Soviet Russian Marriage, Family and Guardianship Code" and the "Russian Federation Family Code" that the Soviet Union's legislation pursues the doctrine of writing and does not provide simple rules on marriage and family. Therefore, the legislative tradition of "should be rough rather than detailed" in China's current marriage law does not come from Soviet Russia. Scholar Li Xiuqing believes that after 1949, due to the influence of the Soviet legislative model, the marriage law was adopted as an independent legal department by Chinese academic circles. Since the promulgation of the Marriage Law in 1950, China has adopted a Soviet-style legislative model that paralleled family law and civil law in the three civil code codifications in 1954, 1962, and 1979. Therefore, the Soviet-Russian tradition created a legislative model in which marriage and family law are independent of civil law, rather than a legislative tradition that should be rough rather than detailed.

Regarding the argument that should be rough rather than detailed, data shows that this is the scientific attitude and method that Deng Xiaoping has consistently advocated to handle and summarize major historical issues. He pointed out many times: "It is better to be rough than detailed when summarizing the past." This sentence means that we should focus on the significant aspects and ignore the details of right or wrong when evaluating history. 
This sentence is Deng Xiaoping's conclusion when summing up the experience of building the People's Republic of China, and its original intention is not to guide the legislative work. After consulting the speeches of prominent Chinese leaders and other related documents, I have not seen the official source of this phrase. It became a consensus view without an official source, which shows that rough rather than detailed is an essential feature of legislative work in China and that the concept has deeply affected many legislators.

\section{The Simplification of the Text of the Marriage Law Should Be Traced Back to the Marriage Law of 1950}

Since the founding of the People's Republic of China in 1949, China's marriage legislation has gone through three laws, including the 1950 Marriage Law, the 1980 Marriage Law, and the 2001 Marriage Law Amendment, and finally changed the legislative style of independence of the civil law. Looking at the four versions of the marriage and family legislation texts, we can see the continuity of the legislative tradition of should be rough rather than detailed. To explain the legislative techniques and value choices of the "should be rough rather than detailed" of Chinese marriage law, and to better understand the state of the simplification and style structure of the clauses in the Marriage and Family Chapter of the Civil Code, it should be traced back to the Marriage Law of 1950. The Marriage Law of 1950 was the product of the victory of the Chinese Communist Women's Movement since the Revolution of 1911. The simplification of the text is determined by the legislative purpose of this law to break the feudal marriage system, protect the rights of women and children, and the nature of the special law. Instead of being influenced by Soviet Russian tradition, the formulation of the law was restricted by the legislative technical difficulties and the social reality faced by the marriage law drafting group centered on women leaders at that time. It was a helpless choice in a particular period.

\subsection{The Marriage Law of 1950 Was a Product of the Victory of the Chinese Women's Movement}

The relationship between the 1950 Marriage Law and the Chinese Women's Movement can be investigated from the process of its formulation. The academic circles once believed that Mao Zedong appointed Wang Ming to preside over the drafting of the 1950 Marriage Law. It is now believed that the draft of the Marriage Law of 1950 was formulated by a seven-member team set up by the Central Women's Committee, with Deng Yingchao as the director. The prominent members are Shuai Mengqi, Yang Zhihua, Kang Keqing, Li Peizhi, Luo Qiong, and Wang Ruqi. Examining the identities and work experience of the members of the group of seven, we can see the strong connection between the Marriage Law of 1950 and the Chinese Communist Women's Movement.

First of all, the members of the Marriage Law Drafting Team are all women. They are deeply aware of the cruel shackles brought by feudal society to women in leading and participating in the women's movement. They share the same feelings with women and hope to change this situation.

Since the Revolution of 1911 and especially the May 4 Movement, the Chinese elite has criticized feudal marriage and patriarchy and advocated women's self-help. The women's liberation and gender equality movement once swept the country vigorously. In January 1924, Liu Qingyang, Deng Yingchao, and others edited and published Women's Daily in Tianjin. It was the country's first newspaper mainly sponsored by women. Liu Qingyang was the general manager. Deng Yingchao and Li Zhishan were all editors of the newspaper. Although Women's Daily has no direct organizational relationship with the Communist Party of China, its founders and principals are members of the Communist Party and the Communist Youth League. It reports and discusses women's issues in novel forms and informative content from beginning to end, inspiring women to think about their status and oppression. The newspaper also frequently reported critical current affairs news at home and abroad to guide women to pay attention to national and social issues, mainly to spread Marxist ideas.

Secondly, the marriage law drafting team members are leaders of the Chinese Communist Party's Women's Movement. They participated in and promoted the early women's liberation movement in China and have practical experience. In 1925, the Guangdong Women's Liberation Association, led by Cai Chang and Deng Yingchao, was formally established in the current Yuexiu District of Guangzhou, calling for the end of the feudal marriage and family system with "oppression and obedience" as the core.

During the cooperation between the KMT and the Communist Party, Deng Yingchao was responsible for the women's movement in Guangdong. Compared with the magnificent labor movement, peasant movement, and dynamic student movement, the women's movement in Guangzhou before 1925 did not progress for a long time. Deng Yingchao wrote an article that pointed out: "Guangdong is the origin of the revolution... The women of this turbulent revolutionary origin have disappointed us. They must not keep pace with the people of all classes. There is no tightly unified organization and no practical plan. "The weak development of the women's movement is mainly due to poor organization, failure to attract workers and peasant women to participate, and lack of exceptional financial support. In this regard, Deng Yingchao said, "The previous mistakes were entirely due to lack of organization... if we ignore the most powerful workers and peasants, the most influential groups of 
women. In that case, it is useless to rely solely on the activities of a few intellectuals. Moreover, if the revolution itself is unorganized, it will not develop sufficiently. Therefore, the foundation of the women's movement in the future should be broadly added to the women of workers and peasants rather than being built on a few people.

Third, Deng Yingchao, the leader of the seven-member group, was influenced by the Chinese feminist thinker Lv Bicheng, and the others also received feminist education. They had a theoretical identity and theoretical knowledge of the Chinese Communist Party's policy of emancipating women in leading the Chinese revolution.

On March 3, 1931, all members of the Central Committee of the Communist Party of China drafted a plan on women's work. The document states, "In order to destroy the legislative standards of the old society, to oppose the exploitative relationships in the feudal family, and to ensure that women enjoy equal rights and allow them to have civil rights, Soviet political principles must be applied to women." The early leaders of the Chinese Communist Party believed that the women's movement and the revolutionary movement were inseparable. In 1938, under the initiation of Deng Yingchao and Shen Junru, the China Wartime Child Care Association was established in Hankou on March 10, with Song Meiling as the chairman and Li Dequan as the vice-chairman.

In January 1949, the Preparatory Committee for the First National Women's Congress was established. Cai Chang was the chairman of the preparatory committee, Deng Yingchao and Li Dequan were deputy directors, and Zhang Qinqiu was the secretary-general. Deng Yingchao pointed out: "Abolishing the remnants of feudal forces, building a unified People's Democratic Republic, and completing the new democratic revolution are the current general tasks of the Chinese women's movement." "The peasant women need a revolution, and the revolution also needs peasant women." This is the conclusion drawn by the Communist Party of China, especially Mao Zedong, after conducting a detailed social survey in rural areas. It is also the guiding ideology of the Communist Party of China in formulating the policies of the women's movement during this period. Whether starting from class interests or in terms of the ideal of emancipating women, women are undoubtedly a vital force for revolution. In the eyes of the Chinese Communist Party, the alliance between women and the revolution is both possible and necessary.

As a product of the Women's Movement of the Chinese Communist Party, breaking the remnants of the feudal marriage and family system and establishing the equal status of women and children are the most fundamental political goals of the 1950 Marriage Law. The law does not focus on the relationship between husband and wife and family structure, let alone the parent-child relationship. It is mainly to free women from the shackles of feudalism and enable them to have a legitimate legal status to participate in social movements and construction. From the very beginning, the Marriage Law of 1950 was inseparable from the social construction of the Republic. It is the continuation of the Chinese Communist Party's women's policy and the ultimate legislative realization. Giving women political status and confirming their rights by law is not a product of the natural development of society. Therefore, the policy significance of this law is more significant than its legal significance. Therefore, the marriage law is formulated for rapid promulgation and renewal of the old, inevitably leading to the law being based on moral norms, with sparse specific norms. Its nature determines this.

\subsection{The Drafting of the Marriage Law of 1950 Was Restricted by Technical Difficulties in Legislation}

First, the drafting of the Marriage Law of 1950 was limited by the knowledge background and work experience of the Marriage Law Drafting Team members. Luo Qiong graduated from Suzhou Women's Normal School in Jiangsu Province in 1932. She participated in the revolution in 1935. As a writer for the Shanghai "Women's Life" magazine, she participated in the Shanghai Women's Salvation Association launch, which united all classes. She served as a council member and director of the propaganda department. Li Peizhi studied at the Second Women's Normal School in Baoding, Hebei, from 1920 to 1925. Yang Zhihua participated in the Fifth National Congress of the Communist Party of China and was elected as a member of the Central Committee and served as the Minister of Women of the Central Committee. In December of the same year, he founded the Chinese Women magazine and authored Introduction to Women's Movement. Deng Yingchao, Kang Keqing, and Shuai Mengqi are also prominent leaders of the Chinese Communist Party's women's movement.

Among the seven members of the drafting team, only Wang Ruqi received professional legal training. Wang Ruqi was admitted to the law department of Fudan University in 1931 and served as the Minister of Propaganda of the Anti-Fascist Salvation Committee of the Women's Circle in Shanghai and the editor-in-chief of "Women in War". On the eve of the fall of Shanghai in November 1937, Wang Ruqi retreated to Wuhan and served as the dean of the women's training class of the Wuhan New Life Movement Women's Steering Committee and a teacher of the women's training class of the Hunan Local Administrative Cadre School. She worked under the leadership of Deng Yingchao. After arriving in Yan'an in March 1940, Wang Ruqi engaged in research work in the Central Women's Movement Committee of the Communist Party of China. In 1941, Wang Ruqi wrote the 
book "70 Million Women Turn Over". At the same time, he served as the first council member of the Chinese Law Society and the first to a fourth executive committee member of the China Women's Federation. The blank legal background of the members of the legislative group made the drafting of the Marriage Law in 1950 inevitably encountered technical obstacles in the legislation.

Second, the text of the 1950 Marriage Law was influenced by the Soviet Union's legislative model and the early marriage legislation of the Chinese Communist Party. In the early days of the Chinese Revolution, the marriage legislation practice of the Chinese Communist Party was influenced by the Soviet Russian tradition. The primary marriage legislation in the period of the Revolutionary Base was the Chinese Soviet Republic's Marriage Regulations promulgated in 1931 and the Chinese Soviet Republic's Marriage Law, which was revised and re-issued in 1934. The interim regulations on marriage and family issues during the Anti-Fascist War include the 1939 Marriage Regulations in the Shanxi-Gansu-Ningxia Border Region, the 1942 Temporary Regulations on Marriage in the Jin-Hebei-Shandong-Hebei Border Region, and the 1943 Marriage Regulations in the Jin-Cha-He Border Region. The spirit of this marriage legislation, without exception, is to break the old feudal traditional marriage and family system, promote equality between men and women, protect the rights of women and children, and give working women equal social, political, economic, legal, and cultural status through marriage legislation. These legislative provisions are not very detailed, and the scope of implementation is limited to the particular period of the border area, so there are defects in the legislative technology. However, it has accumulated valuable experience in the rule of law for the party on marriage legislation, and it was also the main reference document for the subsequent marriage law legislation in 1950.

Third, the 1950 Marriage Law focused on solving two key issues concerning the nature of the marriage law and whether "freedom of divorce" should be included in the marriage law. From discussing the above issues during the formulation of the law, we can also see its focus and historical mission. During the drafting of the Marriage Law in 1950, two issues were focused on. One is whether the marriage law is public or private, and the other is the issue of freedom of divorce. Regarding whether the marriage law is public or private, Deng Yingchao has experienced ideological and cognitive struggles. In her speech to youth league members and progressive youth, Deng Yingchao pointed out that Lenin taught everyone more than once: Gender relations and family issues are not personal affairs or subsections of life. When Deng Yingchao was the wife of the Premier of the State Council and the core figure of the Chinese Women's Federation, she commented on the Marriage Law of the People's Republic of China: People are encouraged to maintain social production and single men and women should fall in love. Love and marriage are matters of personal concern and privacy, and no one or organization has the right to interfere. It is necessary to convince the masses of this. The harmonious development of love and marriage is the essential condition of good social life.

Nevertheless, soon after, Deng Yingchao changed this view. In the end, marriage and family legislation appeared in China in the form of public law. Scholar Li Yongjun believes that legislation based on the transformation of society must reflect the state's comprehensive intervention in marriage and family life. Therefore, the marriage law is no longer an integral part of civil law but has become an independent legal department. Its private law attribute has been denied. The contribution of the Civil Code lies in its realization of the transformation of marriage and family law from political law to civil law.

The issue of "freedom of divorce" was the focus of controversy during the drafting of the Marriage Law of 1950. On this issue, Deng Yingchao clearly expressed his attitude. In the Letter to Mao Zedong, Liu Shaoqi, Zhu De, Ren Bishi, and Zhou Enlai Regarding the Marriage Bill, she advocated the addition of one-party insists that divorce can be divorced. She believes that the marriage law at that time was a principled provision. To destroy the old and build a new one, it is necessary to target the inequality between men and women and protect women. Comrades of the Women's Committee must consider the interests of most women when considering each item of the marriage regulations.

After several months of hard work, the Central Women's Committee drafted the first draft of the Marriage Law, which eventually allowed women to remarry and abolish arranged marriages as the first basic principle established by the new China's Marriage Law, freedom of marriage. The Marriage Law of 1950 also established three other basic principles: monogamy, equality between men and women, and protection of the legitimate rights and interests of women and children.

\subsection{The Marriage Law of 1950 Applies as a Special Law Rather Than a General Norm}

On April 13, 1950, the Marriage Law of the People's Republic of China passed at the seventh meeting of the Central People's Government Committee was the fundamental law promulgated after the founding of New China. In May of the same year, the new marriage law came into effect. From the perspective of the legislative purpose, 
law enforcement process, judicial practice, and social effects of this law, the 1950 Marriage Law was promulgated as a special law rather than a general law and was implemented through campaigns rather than general applications. Together with the "Outline of Land Law" promulgated in the same period, it carries the political tasks of a particular period. The implementation of the marriage law movement itself is more like a continuation of the Chinese Communist Women's Movement. Regarding this, Deng Yingchao has stated: "The new task of land reform and women's work is to focus on land reform and integrate women's work with land reform...to achieve equality between men and women in the land reform movement."

The simplification of the 1950 Marriage Law was due to its unique legal attributes and intentional institutional ambiguity. First of all, the legislative purpose of this law is not the general purpose of adapting social relations to the development of productive forces, but more to abolish the feudal marriage system, protect the rights of women and children, and demonstrate the political propositions of the Communist Party of China. Its legislation is progressive and revolutionary.

Secondly, the law enforcement process after the promulgation of the Marriage Law in 1950 was implemented in a top-down movement. In order to promote the implementation of the Marriage Law in 1950, the Committee for the Implementation of the Marriage Law Campaign was established to carry out the Marriage Law Campaign Month from the central to the local. On January 9, 1953, the 166th meeting of the State Council decided to establish a Committee for the Implementation of the Marriage Law Campaign. On the 14th, the Central Committee for the Implementation of Marriage Law was formally established in Beijing. Shen Junru was the committee director, and Liu Jingfan, He Xiangning, Peng Zemin, Deng Yingchao, Shi Liang, and Xiao Huawei were deputy directors. Following the central government's instructions, the meeting decided that March 1953 should be the month to promote and implement the Marriage Law. All parts of the country, except for minority areas and areas that have not yet completed land reform, should focus on implementing the Marriage Law and the reform of the feudal marriage system.

Third, from the perspective of judicial practice cases, the cases in this period were mainly disputed with female personality rights and status rights and rarely involved cases involving property distribution.

Due to the lack of a correct and comprehensive understanding of the marriage law by some leading cadres, the new marriage law conflicts with traditional marriage concepts and marriage customs, and there have been situations in which marriage system reforms and the implementation of laws and policies have caused damage to women's rights in various places. On the eve of the enactment of the Marriage Law in 1980, the social order of marriage had reached a state of chaos, and there was an urgent need for the promulgation of the marriage law as the object of general order adjustment adapt to the new social family relationship. Only then has the marriage law turned to social law so that the marriage law began to pay attention to the legislative value of the protection of marital property.

Fourth, the social effects of the Marriage Law of 1950. In the 20 years from 1957 to 1976, China experienced a series of political movements, and the marriage and family system established by the Marriage Law of 1950 was undermined. The marriage and family relationship between 1957 and 1976 had a solid political color. At that time, marriage and divorce had to be investigated for political factors, such as the difficulty of finding a match for children of wealthy land in rural areas and the general restriction on marriage with overseas relationships. In terms of the divorce, there was once a rural couple demanding a divorce, but the court decision did not allow it. They wrote in the verdict: "You are all children of poor and lower-middle peasants. There is no fundamental conflict. Why do you want a divorce?" This just shows that the nature of the 1950 Marriage Law is a special law. Its formulation was not based on society's social family status and popular beliefs at that time. On the contrary, it played a new and revolutionary function at the normative level, and with the cooperation of powerful social movements, it had an important influence on the changes of popular beliefs. After establishing the People's Republic of China and implementing the 1950 Marriage Law and 1980 Marriage Law, legally proclaiming the end of the feudal marriage and parental autocracy, the marriage and family system has undergone a historic change.

\section{The Influence and Evaluation of the Tradition of "Should Be Rough Rather Than Detailed" in the Marriage Law}

Under the influence of the legislative tradition of "should be rough rather than detailed" in the marriage law, the simplification of the provisions of the 1950 Marriage Law, 1980 Marriage Law, and 2001 Marriage Law amendments resulted in the lack of some systems and excessive principled norms. To make the "Marriage Law" judgment function need to use judicial interpretation to play, and eventually lead to the Supreme People's Court replacing the National People's Congress as the de facto legislator. 
In drafting and enacting the Marriage and Family Code of the 2020 Civil Code, Chinese marriage and family law experts have discussed whether marriage legislation should abandon the tradition of should be rough rather than detailed and developed in the direction of refined and standardized legislation. Scholar Xia Yinlan believes that "we must grasp the relationship between the coarseness and fineness of the marriage and family legislation, abandon the marriage law's legislative tradition of should be rough rather than detailed for many years, and based on improving the current laws and regulations, adding specific systems, regulations, and measures to realize the scientificity and operability of legislation."

\section{Conclusions}

The social function of law requires it to respond to social development and resolve social contradictions, rather than simply handing over issues in the social transformation to judicial practice. Major legal reforms such as the marriage and family legislation in modern China are all direct responses to social realities. For example, the abolition of the clause of "young family members who disobey the elders' orders shall be punished" in the modern legal reform impacts the traditional Chinese patriarchy. Another example is the impact of the abolition of the clause "consensual sex with unmarried or widowed women shall be punished" on women's rights. As scholars said, "The essence of these disputes lies in two different understandings of the current state of the country and its future." Marriage and family relations in Chinese society have changed over the centuries, and the legal principles and value orientations established in each significant change have become the basis of future laws. Taking consideration of the problems facing Chinese society, starting from the reversal of the traditional legislation of should be rough rather than detailed, and gradually improving the technical aspects of marriage and family law based on trial and error, is the general direction for the development and improvement of China's marriage and family law in the future.

\section{References}

Chang, L. B. (2013). Shaping Marriage Laws and Making Peasant's State Ideals — on the Marriage Laws Made in 1950. Academic Journal of Jinyang, 3, 85-94.

Deng, X. P. (1995). Selected Works of Deng Xiaoping (Vol. 2). Beijing: Thread-bound Bookstore Press.

Deng, Y. C. (1926, January 1). Guangdong Women's Movement in the 14th Year of the Republic of China. Women's Voice, p. A4.

Julia, K. Chinese Women (L. Zhao). Shanghai: Tongji University Press.

Li, X. Q. (2002). Growth of Marriage Law in People's Republic of China and the Influence of the Soviet Model. Science of Law (Journal of Northwest University of Political Science and Law), 4, 76-89.

Ma, Y. S. (1995). Records of Zhou Enlai's Formation and Management of the Government. Beijing: Central Literature Publishing House.

Piao, J. S. (2017). The Contradiction and Compromises on the "Complete Freedom of Divorce": Focusing on the process of Enactment of the Marriage Law of the PRC (1950). Journal of Xuzhou Institute of Technology (Social Sciences Edition), 1, 47-52.

Qiao, Y. (2019). The historical practice and legal reflection of the legislation should be rough rather than detailed. Journal of Southeast University (Philosophy and Social Science), 21(S1), p. 83-87.

Wo, Q. R., \& You, Q. H. (1996). Japanese Civil Law (Family Law) (Y. Z. Xia). Beijing: Industry and Commerce Publishing House.

Xu, D. Y. (2019). The Reconstruction of Marriage and Family Law: Ideas and Details. China Law Review, 1, 109-119.

Zhang, W. C. (2013). The Limits of Liberation: The Women's Movement of the Communist Party of China (1921-1949). China University of Political Science and Law Press.

Zheng, Y. F., \& Lv, M. Y. (2010). General History of Chinese Women (Republic of China Volume). Hangzhou: Hangzhou Publishing House.

\section{Copyrights}

Copyright for this article is retained by the author(s), with first publication rights granted to the journal.

This is an open-access article distributed under the terms and conditions of the Creative Commons Attribution license (http://creativecommons.org/licenses/by/4.0/). 